\title{
Review Essay Back to the Future: Newman on Corporal Punishment
}

Jonathan Simon

\author{
Graeme Newman, Just and Painful: A Case for the Corporal Punishment \\ of Criminals. New York: Macmillan Publishing Co., 1983. Pp. 163. \\ $\$ 13.50$.
}

If there is anything consistent in the history of criminal justice policy it is that no idea disappears for long. The fixed sentence was considered primitive in the 1920s; in the past several years it has been hailed as the solution to the modern dilemmas of punishment. Likewise, by the end of the past century prison labor was considered a scandal that degraded free labor and interfered with prison discipline; today it has once again surfaced on the agenda of prison reformers. Still some readers will find surprising and disturbing Graeme Newman's thesis in his book Just and Painful: $A$ Case for the Corporal Punishment of Criminals.

Newman proposes that electrical shocks, calculated in advance to avoid permanent damage, be employed to give physically painful punishment to many of the offenders who today draw sentences of probation or imprisonment. While Newman would not eliminate the prison, he presents the view that its long-term destructive effect on the lives of those incarcerated is really an inappropriate punishment for all but those who commit horribly violent crimes or who persist in offending. Alternatives like probation, however, are insufficiently punitive to satisfy the basic sensibility of the victimized community. Painful electric shocks can fill the gap, according to Newman.

His argument, which I will summarize-although he himself presents a comprehensive summary in the form of a "punishment manifesto" (at 139-42)-consists of a number of analyses attacking many of the institutions and ideas that have dominated modern penal thought, and rehabilitating the idea that punishment can be legitimately imposed on the body of the offender.

Jonathan Simon is a joint J.D./Ph.D. student in the Jurisprudence and Social Policy Program at the University of California, Berkeley, School of Law (Boalt Hall). A.B. 1982, University of California, Berkeley. 
To resuscitate the idea of corporal punishment Newman first seeks to establish two theses concerning punishment: that it must be painful and that it must reflect the character of the crime itself. To Newman the two theses entail each other. Punishment is for the lawful community, who must feel that punishment has been accomplished if justice is to be done. But this shared experience is obstructed by such abstract punishments as imprisonment and probation. Pain is essential because it is universal, because everyone can understand what it entails, and because it mirrors the pain of crime.

Pain is essential for a second reason that concerns the offender rather than the community. The offender needs to do penance, to expiate his breach of the community's rules. For Newman, suffering is a required element of expiation. It is true of course that imprisonment causes suffering. Indeed, by Newman's account, the problem is that the suffering imposed by imprisonment is too often interminable and pervasive, invading every aspect of the offender's life and attacking his or her family as well.

How is punishment to be arranged so as to reflect to both the community and the offender the nature and relative place of the crime? Newman draws inspiration from the Italian poet Dante of the classical era, who in his famous book about hell described in detail various painful torments that meticulously reflected the particular sins of various famous people of Dante's age and earlier. ${ }^{1}$

Newman understands that the punishments described by Dante are far out of line given contemporary sensibilities. Yet such modern punishments as prison can only attach to each crime an abstract length of time, which may represent the crime's relative seriousness but fail to communicate the nature of the wrong. Retreating from the meticulous reflection of Dantean techniques, Newman proposes at least a basic dichotomy: Those crimes that cause intense but limited harm (e.g., many property offenses, which can be very hard on individuals but limited in their long-term effect) deserve to be met by a punishment that is short but intense, one that spares the offender the life-long harm that imprisonment brings-such a punishment as electric shock. On the other hand, those who commit crimes of great violence permanently affecting their victims, or who through persistent offending cause a widespread harm, deserve the lifetime damage entailed in imprisonment.

Newman's discussion about punishment raises several important questions. Not the least question is whether such notions as expiation and the community's gratification at having punishment rendered speak to any coherent set of social practices and shared meanings in our society. I shall return to these problems. But Newman does not stand completely on a philosophy of punishment; he seeks to motivate the reappraisal of painful corporal punishment by questioning the nature of our current use of the prison.

He argues that everything about corporal punishment that shocks the civilized conscience is true also of prison, but even more so. You say that cor-

1. Dante Alighieri, The Inferno, trans. Dorothy L. Sayers (London: Penguin, 1955). 
poral punishment is torture? Then consider the mental torture of an indeterminate incarceration - the time dependent on the arbitrary decisions of parole boards and the experience entailing constant threat of attack from other prisoners.

You say that corporal punishment invites excess? Consider the excessive prison terms mandated by legislators with little or no practical understanding of what such sentences mean in human terms.

You say that corporal punishment involves violent acts that are themselves corrosive of our social mores? Consider the incessant and uncontrolled violence that is unleashed by prisoners upon one another, including rape and deadly assault. Moreover, consider the violence done to the instincts of people who must maintain custody over caged fellow humans.

Prison is physical punishment, only without intention or plan, and thus without purpose or limits. Moreover the prison goes beyond the body; it lays claim to the very soul of the offender, who is subjected not only to fear and pain but also to the psychiatric assault of behavior modification. Thus Newman agrees that our forms of punishment. ought to reflect our level of civilization and our republican ideals, but he maintains it is the prison-destructive in effect, and totalitarian in form-that undermines our values.

How then did we become mired in a form of punishment that is simultaneously excessive and inadequate? One of the shortcomings of Newman's analysis is his assumption that the fundamental underpinnings of the prison are intellectual. It is true that the history of the prison and the history of penal theory are closely entwined, but the relations of causality are complex. Michel Foucault, for instance, argues that it is the prison that makes modern penal theory possible rather than the reverse. ${ }^{2}$ By targeting the major utilitarian penal theories for analysis and attack, Newman risks missing the web of social practices that make the prison seem inevitable and desirable to social planners.

Newman advances his attack against the utilitarian penal theories that he sees as having historically supported the use of imprisonment: deterrence, the idea that punishments ought to deter the individual offender from future offenses by intimidation and to deter the general population of potential offenders by example; incapacitation, the idea that punishments ought to actually restrain the capacity of the offender to commit further acts of harm, at least for a while; rehabilitation, the idea that imprisonment combined with therapeutic techniques can alter the psychological maladjustments that lead to criminal acts.

Like the technique of imprisonment, Newman argues, these theories (which support imprisonment) are corrosive of our values of individual autonomy. By demanding of punishment that it be socially useful, they erase the link between the offense and punishment. If punishment has its end in socially useful consequences, it can easily become excessive because it loses

2. Michel Foucault, Discipline and Punish: The Birth of the Prison, trans. Alan Sheridan (New York: Vintage Books, 1979). 
any connection to the offender's guilty act. Moreover, the nature of these theories breaks the punitive bond between the offender and the community and puts in its place the state, whose properly limited role in a free society becomes distorted.

While he questions whether they can even deliver the goods they promise, Newman's fundamental objections to deterrence, incapacitation, and rehabilitation are in the form of a political and moral critique. It is true, of course, that physically painful punishments may replicate the effects of deterrence through the experience of suffering and its communication to the public, and true that those imprisoned because they deserve it may also be incapacitated from further offending in the community; but according to Newman, these effects cannot be permitted to primarily justify or guide punishment. The only legitimate goal of punishment is that through the instrument of pain the community's suffering from the crime should be repaid and the offender thus returned to a morally proper place in the community. This theory of punishment, often associated with the philosophers Kant and Hegel, is called retribution.

While many contemporary punishment theorists focus on retribution, ${ }^{3}$ Newman's focus on physical punishment sets his work apart from the major perspectives represented in the contemporary discussion about penal policy. For the reader whose attention is only occasionally drawn to the incessant debate about punishment-when it erupts into the constitutional courts, the state legislatures, and the press-it is difficult to place Newman's ideas in a context and tempting to see them as disturbing, bizarre, or compellingly original.

\section{The Grammar of Punishment Theory}

Without eliminating in advance any of these intuitions, it may be useful to situate Professor Newman's discussion in the contemporary landscape of penal debate. While some elements of his proposal are different, many elements-and justifications-faithfully reproduce a way of talking about central problems facing the management of punishment and about their solutions that is shared by all serious writers on punishment today.

On one level there is considerable diversity among the different theories of punishment advanced in academic, professional, and legislative circles. Most people are familiar with the four purposes customarily put forward for punishing criminals: retribution, deterrence (both special and general), rehabilitation, and incapacitation.

On the policy level most proposals put forth all four goals as simultaneous objectives. Even on the academic level few pursue one goal as rational to advance all by itself. But it is at the legislative level, after the full path of compromise and negotiating has been followed, that the fullest possible confla-

3. Andrew von Hirsch, Doing Justice: The Choice of Punishments (New York: Hill \& Wang, 1976); Ernest Van den Haag, Punishing Criminals: Concerning a Very Old and Painful Question (New York: Basic Books, 1975). 
tion of the purposes is realized. The recently passed Comprehensive Crime Control Act of 1984 is a good example.

The court, in determining the particular sentence to be imposed, shall consider ... the need for the sentence imposed-(A) to reflect the seriousness of the offense, to promote respect for the law, and to provide just punishment for the offense; (B) to afford adequate deterrence to criminal conduct; (C) to protect the public from further crimes of the defendant; and (D) to provide the defendant with needed educational or vocational training, medical care, or other correctional treatment."

Newman blames the present confusion on insufficient clarity concerning the purposes of punishment, but beneath the academic debates and the political struggles, a number of conceptions cut across the field of battle and in fact determine in advance the kind of claims that each participant must make or refute in order to be taken seriously.

These conceptions are historically unique modes of discussing the very real material and ideological dilemmas facing the institution of punishment. Together they form an implicit grammar within which work that is to be taken seriously and recognized by others as relevant operates. Punishment is not alone among organized human endeavors in having such a framework. Professor Duncan Kennedy has formulated a similar approach to analyzing the history of judicial reasoning, which he calls "legal consciousness."

The notion behind the concept of legal consciousness is that people can have in common something more influential than a checklist of facts, techniques, and opinions. They can share premises about the salient aspects of the legal order that are so basic that actors rarely if ever bring them consciously to mind. Yet everyone, including actors who think they disagree profoundly about the substantive issues that matter, would dismiss without a second thought (perhaps as "not a legal argument" or as simply missing the point) an approach appearing to deny them.

While the grammar operating in the contemporary field of punishment is no doubt quite complex, three concepts appear to this author as particularly important: scarcity of penal resources, controlling the rate of crime, rationalizing the decision-making process.

\section{Scarcity of Penal Resources}

Today penal discourses from all schools address themselves expressly, and centrally, to the problem of the scarce resources actually available to the penal process. Andrew von Hirsch, one of the leading proponents of retribution - what he calls "just deserts"-in a recently published debate with other scholars acknowledged the priority of resource distribution. "The unrestricted imprisonmient of felons will simply overwhelm the prisons. It is

4. Comprehensive Crime Control Act of 1984, 36 Crim. L. Rep. (BNA) 3017.

5. Duncan Kennedy, Toward an Historical Understanding of Legal Consciousness: The Case of Classical Legal Thought in America, 1850-1940, 3 Research L. \& Soc. 3,14 (1980). 
therefore essential to supply a workable and systematically-applied standard for deciding which felony cases are important enough to warrant the prison sanction and which are of less importance."'6

Newman takes up the problem at the very beginning of his book and situates the return to painful physical punishment precisely as a solution. "The solution lies in the rediscovery of punishment in all its variety, for there are many punishments that do not need the expensive apparatus of prison and which will do the job of admininstering pain" (at 5).

The concern with fiscal limitations is given prominent attention as well in the specific mechanisms that Newman advances as ways of managing the punishment process. Thus those whose crimes have been severe enough or repeated often enough are in Newman's system given prison as the punishment they deserve and as the one the judge is empowered to impose. Yet Newman gives a veto power over the choice of punishment to a fiscal bureaucracy ("division of the budget"), which can reverse the sentence if prison space is unavailable at the proper level of occupancy.

\section{Controlling the Rate of Crime}

This may not sound particularly new. The goal of every punishment system is the reduction of crime. But what precisely is the target of crime control: Is it the criminal tendency of the individual criminal's personality? The criminal act itself? The target today is not the criminal or the criminal act; it is rather the risk of certain antisocial behaviors distributed within the population. In short, the target of the penal process today is the crime rate as a statistical phenomenon.

Incapacitation is the penal theory that has been most identified with this concept. The theory holds that punishment by incarcerating criminals for a period of time prevents the crimes that they would have committed had they not been incarcerated. Rather than targeting the individual offender who may be redeemed or may be scared into not repeating the offense, or the unknown others who may be prevented by example, incapacitation has its effect in the population considered collectively and statistically, an effect appearing as a certain diminution in the rate at which new offenses are being committed.

This has been expressed most forcefully in the work of Peter Greenwood and Allan Abrahamse of the Rand Corporation. Their program, called "selective incapacitation," proposes using statistical prediction devices to identify convicted offenders who, judged by certain features of their past conduct and experience, appear likely to engage in a high rate of offending while on the street. These people should then be incarcerated more often and for a longer time than those who may have committed the same offense but who

6. Andrew von Hirsch \& Don M. Gottfredson, Selective Incapacitation: Some Questions About Research Design and Equity, 12 N.Y.U. Rev. L. \& Soc. Change 11, 38 (1983-84):

7. Peter Greenwood \& Allan Abrahamse, Selective Incapacitation (Rand Corporation R-2815, August 1982). 
can be predicted to offend at a lower rate. The target of punishment under selective incapacitation is the high-rate offender, whose incarceration has the most direct effect on the crime rate itself.

While incapacitation theory expresses this feature of contemporary penal thought most clearly, the concept operates in all discussion of the subject. Thus Professor von Hirsch, who rejects incapacitation programs like Greenwood's on the grounds that it is unjust to punish people for the crimes they have not yet made the choice to commit, addresses himself forcefully to the data concerning incapacitation effects and prediction success rates. Von Hirsch argues that selective incapacitation will not work. But in taking on this issue in terms of the crime rate, rather than on the purely ethical grounds his own just deserts theory is based on, he acknowledges that this is essential subject matter for penal theory. ${ }^{8}$

Newman also rejects incapacitation-and most harshly. He argues that prediction does not work and that incapacitation has no scientific basis. It further goes against Newman's view because it displaces crime from the world into the prison, where its moral effects are just as outrageous. Newman doubts the capability of prediction techniques; hence he views the emphasis on incapacitation as leading to too much use of imprisonment (the only penalty that seems to perform incapacitatively) (at 105-8).

Yet Newman's own design for selecting which offenders will receive incarceration is completely compatible with a selective incapacitation approach. The public is by Newman's own account fundamentally motivated by the fear of criminals, and it is fear that supports the use of prison as a means of incapacitation.

The point to understand is that fear is a very effective motivator, and that it is this fear of crime in the streets that lies at the bottom of a strong societal pressure that all criminals be put behind bars. It is very likely that this fear of criminals roaming the streets accounts for our obsession with one form of criminal punishment today: prison. (At 108)

Yet the all-important decision of where the line should be drawn between corporal punishment and imprisonment in Newman's system is left precisely to the local judges and prosecutors, the officials most likely to be influenced by the political pressure of public fear of crime. "[Because of the] fact that we cannot predict who will be dangerous at a rate any better than chance..., it is better that the public's fear of horrible criminals be the deciding factor in who gets locked up and who does not" (at 58).

The only limit to the incarceration rate demanded by considerations of fear of crime in Newman's system is the fiscal wisdom of a state bureaucracy. This may indeed be an effective way to make incapacitation "selective," but it is not a way based on retributive concerns of deserts and moral outrage.

The point is not to take Newman to task for the inevitable disjunction between theoretical principles and practical applications. One of the best as-

8. Von Hirsch \& Gottfredson, supra note 6, at 22-23. 
pects of Newman's effort is his willingness to take on the implementation issues that many theorists leave out entirely. Yet it is important to be sensitive to the concrete mechanisms that operate the actual system being proposed by Newman (and that proposed by any other scholar). Long after the debate over policy is over, the character of the actual operating mechanisms continues to have a profound effect on those people handled by the system. This surely has happened with the parole system dominating penal practice from the 1920 s until the present. Parole theoretically has depended on diagnostic techniques that could effectively separate inmates who had been rehabilitated and those who required further correction (i.e., imprisonment). But such techniques have never been developed. Parole boards, faced with the need to make decisions, have worked out their own accommodations-accommodations never anticipated or debated.

There is, of course, such a risk in every theoretical enterprise. But, as argued below, Newman's ideas in particular are vulnerable to colonization by very different mechanisms that would structure the actual operation of a system created to Newman's specifications, because they lack a genuine connection to our contemporary social practices.

\section{Rationalizing the Decision-making Process}

All theories of punishment include a process for determining the extent and character of punishments. The rehabilitation theory, for instance, viewed the decision as one based on "scientific" and "diagnostic" techniques and the decision maker as a skilled expert capable of employing such techniques. Thus the importance of the parole board in all rehabilitative schemes: Since the length of incarceration is to be determined by experts appraising the inmate's progress or the lack thereof, it can hardly be left to a legally trained judge sitting before the start of imprisonment.

The wave of sentencing reform that has spread through the United States since the early $1970 \mathrm{~s}^{9}$ has placed great emphasis on the decision-making process. But rather than offering an alternative approach to decision making, much of the reform discussion has attacked decision-making power itself (often called discretion) as inherently subject to abuse and corruption.

Some further thinking and some actual experience with reformed systems have deepened the more recent analysis of discretion. Penal reformers have realized that attempts to limit discretion at one point of the system inevitably put more unreviewable power in other hands. ${ }^{10}$

In the wake of some of the early reform attempts and disappointments there has arisen an emphasis on linking the individual punishment decision to an accurate picture of the whole system. This can be called "rationaliza-

9. Franklin E. Zimring, Sentencing Reform in the States: Lessons from the 1970s, in Michael H. Tonry \& Franklin E. Zimring, eds., Reform and Punishment: Essays on Criminal Sentencing (Chicago: University of Chicago Press, 1983).

10. Id. at 13 . 
tion," because it brings to the penal field a rational bureacratic style that long ago came to dominate our business enterprises.

A modern retail enterprise would not dream of allowing prices to be set by store managers according to their "clinical" view of local customers, or of allowing prices to be set in stone by a central body meeting every several years. Prices ideally reflect a comprehensive analysis of the state of the market, and the financial position of the enterprise.

In marked contrast, the traditional operation of the prison system has largely been controlled by broad legislative acts, which are manipulated over time to suit the needs of local operators such as prosecutors and judges. Little if any explicit attention has been paid to the overall fiscal capacities and priorities of the system-until a prison riot or court order has brought the issue into public focus.

The drive to rationalize the functioning of the decision-making process in sentencing points toward the need for systematic controls that bring to bear on the individual sentencing decision the actual capacities and purposes of the penal system. An excellent example of this is the Minnesota determinate sentencing system, which has been widely praised and copied. ${ }^{11}$ The Minnesota Sentencing Commission was appointed to set up a new scale of penalties and new rules of sentencing procedure. It operated under a retributive view of punishment, but its most successful device was the idea of limiting in advance the total level of incarceration by the fiscal and physical capacity of the Minnesota prison system.

This approach is analogous to the veto power of the fiscal bureacracy over prison sentences in Newman's plan. Both speak the language of retribution but distribute decision-making power so as to rationalize the results of the punishment process considered as a whole.

While not an exhaustive list, these three concepts among others constitute a grammar within which various competing theories and proposals operate. In a sense they help remind us how limited the room for thinking is. In the criminal justice system, just as in all fields of organized knowledge and policy making, ideas that are to be taken seriously must of necessity move within the often narrowly drawn background rules that shape how problems are perceived and solutions imagined. It is most useful to have a sense of this grammar, especially when examining a proposal so apparently different as that put forward in Newman's book.

It is more difficult to step back from the central concepts in an area like criminal punishment and attempt to interpret what is at stake in the predominance of a certain grammar of punishment. This is a tenuous task when carried out upon eras that are past, but such a project has at least the advantage of hindsight. A far more speculative approach is called for in appraising the structure of contemporary thinking. Nonetheless, inquiring into the significance of the grammar helps us to get some sense of what might be truly 
revolutionary in the various approaches different theories of punishment management take in the face of common problems.

The importance given to the three issues discussed above cannot completely be explained by objective historical developments. Prisons have always been crowded, and the resources expended today on punishment, as well as on other social institutions, would shock the conscience of a pre-New Deal expert.

Crime has of course always been a problem in some sense; what is unique today, however, is a particular way of focusing on crime as a phenomenon of the population perceived statistically rather than as individual or group pathology.

Decision making in the criminal justice system has always been subject to large pockets of unaccountable discretion, and not a little criticism about it from various sides is to be found in the historical archives of state prison commissions and legislative committees.

A more useful approach is to consider the kind of knowledge that is permitted to represent the state of affairs facing the punishment system. A whole history could be written about the role of the changing character of statistical knowledge in shaping the justice system. Simple techniques of record keeping at the outset of the nineteenth century permitted the development for the first time of a picture of individual deviance. The "recidivist," that dark figure that has haunted the penal imagination for a century or more, was born from the simple capacity (by today's standards) to verify identifications and keep track of how many times a person had been imprisoned. ${ }^{12}$

Today a vastly more sophisticated statistical knowledge suggests that two important capacities will soon be practical. First would be a comprehensive and self-updating picture of process in the criminal justice system from arrest of a suspect through termination of sentence or other final disposition. Econometric models of the system could show the effect of current practices at all levels of the system as well as project the benefits of various alternative practices.

A second use of statistical modeling has already lead to a vastly more sophisticated knowledge about "criminal careers": not only the record of an individual offender, but the construction of a normative picture of a typical offending career-when it begins, reaches its highest rate of offending or highest risk of violence, and when in turn it begins to taper off. ${ }^{13}$

Together these new intellectual technologies go a long way toward understanding the grammar of punishment theory. If the scarcity of resources is viewed as a problem that must be addressed, we should credit those models

12. Foucault, supra note 2, at 251-56.

13. This literature is already rather vast, but for a sampling of the kind of work being done one might read Alfred Blumstein \& Jacqueline Cohen, Estimation of Individual Crime Rates from Arrest Records, 70 J. Crim. L. \& Criminology 561 (1979); Alfred Blumstein et al., Demographically Disaggregated Projections of Prison Populations, 8 J. Crim. Jus. 1 (1980); Joan Petersilia et al., Criminal Careers of Habitual Felons (Washington, D.C.: Department of Justice, July 1978). 
that permit a more precise picture of the system's costs, inefficiencies, bottlenecks, and effectiveness. If "crime rate" is the target that every punishment process must aim at, one should recognize that such a target has become a visible object for policy only relatively recently and only through developing statistical knowledge about typical criminal behavior. Finally, if we have come to view it as imperative that decision making be rationalized, this is in great part because we have now a very precise picture of what one could call the economy of decision making - the local needs that motivate it and the broad system-wide effects generated by local practice.

\section{Punishment and Contemporary Social Practices}

All of this may help us understand what has changed to allow the particular grammar of the punishment theory field that we find ourselves compelled to speak in terms of, but it does not tell us what is at stake. One hypothesis is that our social perception that crime and punishment are very special moral and political problems that help define us as a community is a waning perception. Consequently an investment of capital and attention beyond the simple social return from such activity is coming to seem irrational and intolerable. In short, criminal justice, increasingly penetrated by techniques of representation that allow its costs and benefits to be as readily concrete as those of any private corporation or public agency, is coming to be seen as just another social response to a social problem that can be weighted and compared to other social problems such as car accidents, industrial injuries, or illiteracy rates.

The shift in social practices that brought society to tremendous reliance on the prison paralleled a historically unique investment of political and moral concern with the criminal and the means of punishing him or her. This is now arguably being reversed. David Rothman, in his study of the origin of the asylum, the prison, and the other great closed institutions of control in America during the Jacksonian period (the 1830s), has suggested strongly that the prison was linked to a new social perception that the criminal and his or her punishment held the key to social harmony and progress. This is why, Rothman argues, the debate around the precise form and style of prison life took on so much intensity during that period. "With the stakes so high and the results almost entirely dependent upon physical design, every element in penitentiary organization assumed overwhelming importance. Nothing less than the safety and future stability of the republic was at issue, the triumph of good over evil, or order over chaos." 14

Contemporary penal thought emphasizes how to minimize the burdens and maximize the benefits of punishment. The task of punishing the criminal offender has been stripped of its millenial and redemptive features.

This tendency in social sensibilities helps explain the particular grammar of punishment theory that I have outlined above. Yet a strong element in contemporary punishment theory and practice seems to buck this disinvestment of crime and punishment.

14. David J. Rothman, The Discovery of the Asylum 85 (Boston: Little, Brown \& Co., 1971). 
Newman's approach exemplifies this. The core of retribution is the idea that punishment has a moral basis linked to, and necessitating, the pain of the offender - $a$ basis that precludes cost-benefit analysis. At the heart of the vigor Newman brings to his analysis is a conviction that genuine punishment of criminals is essential to our survival as a moral and political community that preserves the autonomy of individual subjects. Everything about his view would appear to denounce the leveling process that would have punishment become comparable to every other bureacratic management problem.

Newman's emphasis on corporal punishment provides an excellent opportunity to inquire into what role the retributive ideal can play in the modern context. By targeting the body of the offender for electric shocks and long fixed prison sentences Newman's proposals go beyond the recent reforms that trumpet retribution while proposing only quantitative changes in the character of the punishment process.

Since Newman suggests creating a punishment process that would emphasize the difference between punishment and other social practices, we need to look more carefully at his vision of painful punishment.

Newman brings forward a scathing criticism of the "humanitarianism" of imprisonment. However, his debunking leaves in place the idea that humanitarianism of an erroneous sort lies behind the modern obsession with imprisonment. Yet as a substantial body of historical work attests, the shift to the prison was not primarily a change in the sentimentality of society, rather it is to be seen as part of a more general change in the manner of managing social tasks that took place more or less contemporaneously in schools, workplaces, hospitals, and welfare agencies. ${ }^{15}$ Thus, whatever it is that binds us to the prison as a technique of punishment, it is more than just a philosophy that can be refuted or debunked; it is a general way of organizing social life, a way whose roots must go deep into our practices.

But what characterized punishment techniques in the age before the prison came to dominate the thought of punishment? Historians like Foucault, Rothman, Melossi, and Pavarini, who have studied these practices, suggest that punishment played a role of reenforcing other social practices-that is, it did not refer only to itself and its moral ends.

Rather than being a useful institution in a world of useful institutions, punishment then thrived as a spectacle. The severest punishments were political rituals of the highest order. The great executions, relatively rare but highly celebrated, presented an occasion for authorities-who had neither a bureacracy nor direct mail to keep in contact with their subjects-to manifest themselves in supercharged and highly structured events. By Foucault's account, corporal punishment (at least at its spectacular margins) combined the body of the condemned offender, the visibility of punishment, and the active presence through agents of the princes of the state, the church, and the law

15. Foucault, supra note 2; Dario Melossi \& Massimo Pavarini, The Prison and the Factory, trans. Glynis Cousin (Totowa, N.J.: Barnes \& Noble Books-Imports, 1981); Rothman, supra note 14. 
into a ritual that helped give meaning and strength to the whole structure of power in society. ${ }^{16}$

All these elements appear in the reconstructed corporal punishments proposed by Newman. It is the body that will be subjected to painful electric impulse, and this will be made visible to the public by allowing representatives from various organizations to watch (at 42). Yet it is difficult to see what meaning this ritual can have to our wider social practices.

Consider the importance highly visible rituals played in traditional corporal punishment. As suggested above, these rituals helped to manifest and strengthen the power relations in traditional society. It is important to see, however, that punishment was not alone in its emphasis on ritual. Rather, punishment's capacity to reinforce the social order stemmed from the fact that it reflected the numerous other rituals that structured social life. From coronations to royal funerals, from baptisms and marriages to the highly ornate art of traditional warfare, premodern and early modern Western society resonated with mutually enforcing references of shared social rituals.

It is not that our own society lacks rituals altogether. As powerfully demonstrated in the work of Erving Goffman, ${ }^{17}$ even our most rationalized bureaucratic institutions are full of rituals that help shape people's identity at the microlevel of social relations. What is absent is the tremendous visibility of the great public rituals. Today, for most of our institutions, visibility is something to be minimized and controlled.

It is not possible in this short an essay to do justice to the modern state of social rituals. My point is a simpler one. Given how important the relationship between punishment and the form of other social practices is to the functioning of punishment in society, we ought to be wary of a proposal that imitates the structure of premodern practices. In short, Newman's punishment ritual fails to speak to the experience of living within our own modern rituals and practices. It is like going to a modern agribusiness corporate farm and finding a rain dance in progress; one has to ask "What is this for?" Newman emphasizes its moral role:

We use this word [penance] not in the medical sense of the modern penologists, but in the sense that, through a sufficient amount of suffering, the offender can come to understand the evil of his offense. This does not mean that he has been "corrected" in the sense that he will not commit his offense again, but rather that he has come to terms with his crime, having fully suffered for the evil he has committed. (At 100-101)

I may be a particularly secular and jaded person but I must confess to an inability to understand what this means. It is not that I disagree; it is that literally the relationship between suffering and evil, which seems to be the central axis around which the punishment ritual turns for Newman, bears no relation to the social practices I inhabit and the experiences I have in them.

16. Foucault, supra note 2, 32-69.

17. Erving Goffman, Interaction Ritual (New York: Doubleday \& Co., Anchor Books, 1967). 
And I suspect that this is true for many people in our time. Revenge, fear, and anger we no doubt feel, and perhaps these could motivate support for corporal punishment, but these are different from the moral calculus of expiation, suffering, and evil.

Yet one does not need to rely on subjective reactions. The key decisionmaking points in the system Newman proposes are structured not by this expiative logic but by the all-too-utilitarian concepts discussed above. Newman leaves it to local pressure to choose between electric shock and prison while acknowledging that popular sentiment is fueled by fear and seeks incarceration for incapacitative rather than moral purposes. Furthermore, he would give veto power over this decision to a bureacracy charged with fiscal responsibility rather than with expiation.

This brings us to a central paradox, brought out by the strong character of Newman's proposals but reproduced in the numerous proposals for retribution that have gone along with recent sentencing reform in many states. Even though retribution seems to operate against the trend toward eliminating the specialness of crime and its punishment, it can operate only within a decisionmaking process structured by the very concepts that constitute this relativizing tendency.

\section{Conclusion}

At the outset of this review we set out to demonstrate that Newman's proposals, while quite different on the surface, are actually organized in depth by the basic grammar of all modern punishment theory. This may have seemed an exercise in the obvious. After all, Newman is a professor of criminology. It is not surprising that his ideas should fit with the prevailing forms of penal theorizing.

Less obvious is how truly narrow the room for thinking and imagining the future of punishment really is. In the 1830 s and 1840 s, punishment reformers engaged in a massive debate between two models of prison regimen. One, at Philadelphia, included a regimen of silence and absolute isolation, even during work time. The other, at Auburn, New York, included a program of silence and partial isolation, including work done with other inmates but in silence, and isolation at night.

Today these two systems strike us as remarkably similar, even though at the time they were thought to represent a stark choice. Might it not be that our own thought, no matter how broad and diverse it may seem to us, might from some future vantage reveal itself as a narrow set of permutations of some basic grammatical conceptions.

Because Newman's ideas seem so radical, they offer the opportunity to explore just how broad the space for thinking is. When his proposals are questioned as to how they will operate, as we have questioned them, the space revealed is soberingly small.

While no great rush of support has so far greeted Newman's proposals, do not count them out. Because prison space is so costly it may come to seem ra- 
tional to replace prisons with high technology surveillance devices that can transform a person's home, car, and work space into a prison cell. ${ }^{18}$ Since the most widely shared purpose for punishment today is the incapacitation of dangerous offenders, there is no reason not to reserve prison for only the most violent and persistent offenders.

If the prison really is replaced for many criminals by surveillance, the prospect of a short and inexpensive form of punishment might well seem attractive to policy makers who realize the public would consider surveillance alone insufficiently punitive. The irony is that while Newman perceives corporal punishment as a ceremony to revive the moral distinctiveness of punishment, it may depend for its realization on the further transformation of punishment into a rational modern enterprise of amoral risk distribution.

Nothing could be more important now in the field of criminal punishment theory than careful exploration of our social practices and the place that punishment plays among them. Once we become conscious of how narrow the current field for imagining alternatives to our present punishment practices really is we may be inspired to question the very meaningfulness of the present grammatical rules within which the discussion takes place.

Consider how in our society different sorts of harmful events result in much different social responses. A person who suffers an "accident" behind the wheel, or on the job, will find that our public policy has erected a vast system of compensation. Our law of "accidents," called torts, has for a long time stressed prevention, mitigation of loss, and victim compensation. A person who suffers a "crime" such as a mugging or a rape will find that our public policy has erected a vast and expensive system that by and large turns its back on the victim while it pursues, against high odds, the capture and punishment of the perpetrator.

Newman is right that punishment seems more and more confusing to us because our modern forms of discussing policy focus on useful consequences. His proposal aims at preserving the special character of punishment by defying the very demand that it be useful. It is worth considering what it would be like to resolve the contradiction in the other direction.

One might start with a question concerning the very grammar of our policy formation: What is it about the difference between "accidents" and "crimes" that requires such a vastly disparate social response?

18. Gary Marx, I'll Be Watching You: The New Surveillance, 1985 Dissent 26. 
HeinOnline -- 1985 Am. B. Found. Res. J. 9421985 